\title{
Quotation/Parenthesis Qur'an Verse Before Beginning Deed In The Structure Of Notary Deed In Sharia Financial Institutions' Contract
}

\author{
Sandy Aji Usman'1, Rasiam² \\ 1,2Universitas Islam Negeri Walisongo Semarang, Indonesia \\ sandy_sajati@yahoo.com
}

\begin{abstract}
Purpose - This research aims to reveal and describe the issue of Islamic financial institutions' contract structure, the practice of the Qur'an quotation/parenthesis in the notary deed structure in Sharia financial institutions' contract.
\end{abstract}

Method - The method used in this research is normative juridical, with the processing and analysis of data in a qualitative descriptive way, this research data is sourced from secondary data and supported by interviews from sources as supporting data Secondary. The approach is to study with the regulatory approach of legislation.

Result-In Islamic Sharia or fatwa is not regulated about the structure of the deed on the deed authentic or under the hands, but which is governed only the principles or basic rules only. Structure of authentic deed made by notary official, especially the deed in financial institution that includes quotation of Qur'an verses using Indonesian language before deed title does not violate the provisions of UUJN.

Implication - The absence of the form of the standard structure of sharia agreement both for sharia transactions and in particular sharia financial institutions should be the financial Services Authority in collaboration with the organization of Indonesian Notary Association (INI) who is already experts to Making authentic deed in the form of raw in accordance with UUNJ.

Originality - The focus of this research is to reveal and describe the issue of Islamic financial institutions' contract structure.

Keywords: Citation of Contract; Inserts of Contract; Deed Structure; Sharia Financial Institutions. 
Sandy Aji Usman, Rasiam

\section{Introduction}

Financial institutions have a major role in a country system around the world, financial institutions so far we know are divided into two namely financial institutions Bank (LKB) and non-Bank financial institutions (LKBB) now known as Non-Bank Financial Industry (IKNB), whether using conventional systems or using Sharia principles. The function of the financial institution is to raise Community funds in the group Ultimate Lenders and distribute back to the community of Ultimate Borrowers. The development of Sharia finance industry in banking, insurance, pawnshop to capital market, becomes the idea that sharia finance continues to strengthen its existence.

Information Technology (IT) is now also known as the Non-Bank Financial Industry (IKNB) based on the technology of Fintech with Peer to Peer lending (P2P Lending) system which is now newly registered and licensed per April 2019 as much as 106 companies Consisting of 102 conventional Fintech companies, conventional and sharia Fintech companies, and Sharia Fintech companies (www.ojk.go.id). The characteristic of shariabased financial institutions provides an alternative to facilitate and benefit the community and the financial industry. Sharia financial institutions have the characteristics to the individual's existence from conventional industry, it brings out the aspects of fairness in transaction, ethical investment, promoting the values of togetherness and brotherhood in The production, avoiding speculative activities in financial transactions.

Every financial institution in investing and channeling funds must carry out the prudent banking principle as included in the international laws and customs. One form of caution is about the legal relationship between the company and the consumer that after the parties agree to be harvested in the form of an agreement or in a positive law known as the Treaty made authentically Created under structured hands. The Agreement relating to financing based on sharia principles, including: Mudharabah Contract, Musyarakah Mutanaqishah, Ijarah Contract, Murabahah Contract, Istishna Contract, Salam Contract, Qard Contract. But there are also other contract 
such as Tabarru Contract, Tijarah Contract, Qardhul Hasan Contract and other contract adapted to the characteristics of the industry or financial institutions Sharia. Each Sharia financial instrument has the underlying Syaria foundation not merely the name or form of the product, it is based on the relationship between the financial institution and the customer that establishes the rights and obligations of each party. The development of products and the agreement on Sharia financial products globally can be seen in the following table 1.

The agreement referred to in the Civil Code of Law/Burgerlijk Wetboek (BW) in Sharia law is known by the word contract. The word contract plays an important role in society, and it indicates that we cannot escape the name of the agreement or the contract. It is "the basis of the many activities of our daily life. "It is certain that contractcan notbe separated from our daily lives. Given the importance of the agreement, every human civilization that has ever emerged gives attention and arrangement to it. With the religion of Islam, which gives the principles and foundations of the arrangement of the Covenant as contained in the Qur'an and Sunnah of the Prophet Muhammad Saw. These fundamentals were developed by the later Islamic practitioners or thinkers known at present with the law of Sharia treaty. The basis of contract in the Qur'an means: "O you who have believed, fulfil [all] contracts (deeds)..." (QS Al-Maidah, 5:1).

Table 1. Global Sharia Finance and Product Development.

\begin{tabular}{lllll}
\hline Product & 1970s & 1980s & 1990s & 2000s \\
\hline Murabahah & $\bullet$ & $\bullet$ & $\bullet$ & $\bullet$ \\
jjarah & & $\mathbf{0}$ & $\bullet$ & $\bullet$ \\
Takaful & & & & \\
Murabahah & & & $\mathbf{0}$ & \\
Sukuk Ijarah & & & Fully applied \\
Asset based financial instrument & & Partially applied & \\
\hline Description: & $\bullet=$ & Partially applied & \\
& $\mathbf{\bullet}$ & &
\end{tabular}


Sandy Aji Usman, Rasiam

Akad or in English is contract, is principally enacted with words, but not the only way, in a financial institution using contract Bi Al-Kitabah (contract by writing), it is a matter of prudent banking principle in Running operational, Fintech brings a big impact on financial institutions, especially the ordinances of the law and payment systems that do not know the space and time, where the parties do not speak and absent (occult), then necessary instrument goodcontract structure according to positive law and Islamic sharia. A treaty made by contract $\mathrm{Bi}$ Al-Kitabah There is also a stated contract of business is a promissory agreement between two or more parties that may give rise to, codify, or eliminate Legal relations. The many forms of sharia financial institutions and products owned require a standard of treaty or contract structure.

From the background of the researchers took the problem that can be formulated in this research is how the structure of the Islamic financial institution' contract structures according to sharia, how the power of the law of the structure of authentic deed of sharia financial institutions that use quotations/inserts Qur'an verses before the beginning of the deed.

\section{Methods}

The method used in this research is normative juridical, with the processing and analysis of data in a qualitative descriptive way, this research data is sourced from secondary data which is a primary legal material consisting of the Book of Civil Law Deed, Law No. 2-year 2014 on amendments to law No. 30 of 2004 on the Department of notary, Law No. 21 of 2008 on sharia banking, compilation of sharia economic law, along with Objects relating to the library books, articles, journals, and other supporting materials from the Internet, supported by interviews from speakers as supporting secondary data. The approach is to study with the regulatory approach of legislation. 
Quotation/Parenthesis Qur'an Verse Before ...

\section{Results and Discussion}

In general the agreement is not tied to a letter of a particular form, can be made orally and if the word is made in writing, then this agreement is as a means of proving in case of disputes. For some treaties the law determines a certain form, if the form is not obeyed, the Treaty is not valid, thus the written form is not merely a proof tool, but is a condition of existence ( Bestaanwaarde) Agreement.

The agreement in the positive law in Indonesia is governed in book III of the Civil Code (KUH Perdata) which adheres to the open system (Openbaar system), but concerning the structure of the agreement is not regulated in a strict manner, only govern The basics of the agreement, regarding the agreement of the civil KUH is complementary, meaning that the parties may deviate from the chapters contained in the civil law. The form of deed as a means of proving in the civil place is contained in article 1868 mentions "an authentic deed is a deed made in the form of a prescribed law by or in the presence of an authorized general officer for it in place Deed was made", if viewed from the form then the deed in two, namely the deed authentic and the deed under hand.

The deed under the hand does not have any form or structure in the civil law because it is based on the principle of article 1338 chapter (1) of civil Law on freedom of contract (freedom of contract) is a principle stating that any approval made in accordance With the law applies to those who make it. From the chapter it can be held that the intent of each party is free to enter into a treaty, the parties freely can make a treaty that includes; Freedom to determine the will to close or not close the agreement, to choose with which party will be closed an agreement, to establish the content of the agreement, to establish the form of agreement, to establish the way of closure of the agreement. Thus, that the Community or the parties to make agreements may include; Agreements that have been governed by law, and any new or mixed agreements that have not yet been governed by law. The principle of contractual immunity makes a treaty containing and any kind of origin not contrary to law, morality and public order. So that the agreement or 
Sandy Aji Usman, Rasiam

agreement made has fulfilled the article 1320 the civil KHU which is agreed, capable, certain objects, and the cause of lawful legal action between the parties.

Before discussing about general officials notary according to positive law, notary work has existed during ancient Rome around the 2-3 century known as the man who noted the speech is called Scribae, Tabellius, while in the Islamic world the notary profession is alreadyknown as it is stated in QS AlBaqarah (1:282),

In accordance with the deed under the hands, to make a deed, agreement or contract, and the determination required by law in the form of authentic deed in whose authority is given to the notary pursuant to article 15 of Law No. 2 Year 2014 on the amendment of Law No. 30 of 2004 on the Department of Notary (hereinafter referred to as UUJN). Article 1 chapter 1 UUJ mentions; "Notary is a general official of his authority to create an authentic deed and have other powers as referred to in this law or under other laws", notary as a general officer in the UUNJ is a position that Specifically based on the law given from the Department as contained in article1868 of the Civil Code, but the notary office is a Lex Specialise from the civil law. The deed made by notary official has the power of law as the strongest and most complete proof tool.

The authentic Deed of notary is a deed (evidence) made by or before a notary according to the form and Ordinance stipulated in the UUJN has the storing of the deed that has been standardized as stated in the article 38 UUNJ, namely: Each deed consists of; Preliminary deed or deed head; Main deed and; End or conclusion of deed; The beginning of deed or the head of deed contains; Title of deed; Deed Number; Hour, day, date, month, and year; Full name and seat of notary position.

Main deed contains:

Full name, place and date of birth, nationality, occupation, position, the appeasers residence and/or person they represent; The description of position appeaser scat; Content of the deed which is the will and wishes of the 
interested parties; Full name, place and date of birth, nationality, occupation, position,and each of the identity witnesses residence.

Final closing of deed contains: The description of deed reading is as intended in article 16 chapter (1) Letter M or constutitution 16 chapter (7); The description of the signing and place of signing or translating deed if; Full name, place and date of birth, nationality, occupation, position, and each of the identity witnesses residence and The description of the absence of changes in the making of the deed or description of changes that may be in addition, scribble, or replacement and the amount of its changes.

Further in article 43 mention that: The deed must be made in Indonesia language; In the event that the theappearers does not understand the language used in the Act, notary shall translate or explain the content of the deed in a language understood by the appeasers; If the parties require, the deed may be made in a foreign language; In case the deed is made as intended in chapter (3), the notary must translate it into Indonesian language.

Judging from the above article can be concluded that the outline of the deed structure consists of the beginning of the deed or the deed head, deed body and, final or concluding deed. Freedom of contract regarding that the parties are free to determine the contents of the agreement in the structure of the authentic deed is reserved in place on the contents of the deed on the part of the deed. Violation of the provisions of article 38, 39, 40 UUJN can make the deed have the power of proof under the hand, other than that in the authentic deed there is an obligation to use the Indonesian language, and if there is a sentence using a foreign language then notary must translate into Indonesian language.

Generally our society in making the agreement is not complete, so that if it is not set in more detail by the parties then the Naturalia applies where the Under has set it in the KUH civil. The Naturalia part is not an absolute part but can be ruled out, it is in accordance with the Openbaar book system III KUH Civil Code, except the deed whose form is determined by law such as the establishment of a legal entity, Buy and sell, the right of the The contents of 
Sandy Aji Usman, Rasiam

the deed can be specifically promised by the parties called the Accidentalia as underachievement of contractual freedoms. The role of notarial skills is important to pour the good and correct will, considering that the parties only convey the essence of the main issue.

Structure of deed according to Islamic law. Islamic law is the principal law of the Qur'an and Hadist. As Ilahiyah law, Islamic law has more value than the content laws that often contain the subjective bias of the author. The value of the above is derived from the creator of the most Fair, Supreme, Almighty and other values of perfection reflected in His attributes.

According to Masjduk Zuhdi: Muamalah is all the provisions of religion that govern the relationship between human beings, both religious (faith) and not as religious, between man and his life, and human beings with natural surroundings. The function of the Qur'an and Hadist as Al Ushul (Basic Provisions), the rule of the mualamah is all things can be done along no prohibition or evidence that forbidden it.

Words that have a similar understanding to the Covenant are the word contract. The word contract (al-'aqdu) means binding, connecting or linking, contract or agreement or deal or transaction can be interpreted as a framed commitment with sharia values. Article 20 the compilation of sharia economics law mentions; "Contract is a deal in an agreement between two or more parties to commit or not to do certain legal acts." One of the principles of the Sharia Economic law compilation mentions to do an agreement is AlKitabah (written), it is not an absolute or compulsory but is inscribed in writing, because there is the principle of Al-Hurriyah (freedom Contracting), the Parties remain able and permitted to make an agreement in accordance with the principle of freedom of contract (AL-Hurriyah), but while adhering to the underlying provisions established to protect the interests of sharia principles, legal Positive and Consumer protection, This freedom of contract is a limitation that should not contradict Islamic syriic, legislation, public order, and its nature. The most fundamental thing to distinguish the agreement according to Islamic sharia with positive law is to commit the law (Contract) that not only bind to the parties that is between human and human 
(horizontally) alone, Mamun also bind Between the Parties and God (vertically).

Contract required Al-Kitabah (written) but about the form or structure of the deed on the contract is not regulated, but the Qur'an and Hadist have laid the principles and foundations in a more detailed manner in order that a contract can be judged legitimately. The legal requirement of an agreement must be fulfilled and the agreement of contract. The compilation of Sharia economics law and the terms of the agreement mentioned in Article 22 contract consist of: The parties doing contract; Contract object; Purpose/Main contract; Agreement.

While contract requirement in the article 23-25 consists of: Article 23, Parties who are engaged are persons, alliances, or business entities who have an proficiency in performing legal action; Article 24, Contract object is amwal or halal services required by each; Article 25, Contract aims to fulfil the needs of life and the development of the business of each trust that holds contract.

The development of business in the modern era is now increasingly fast and varied almost impossible for business people to conduct orally only, the greater and the length of time the business run, the more complex contracts or the contract. With the bond in writing, it reflects the form of professionalism in the management of an accountable and credible business. Financial institutions in the contract can be determined by Al-Kitabah (written), concerning the form or structure of the contract is not specifically regulated in the law as well as the structure of the deed set In UUJN. Otoritas Jasa Keuangan $(\mathrm{OJK})$ as an institution that organizes regulatory systems and supervision over financial services sector activities has issued product standard books in accordance with sharia products, various forms of Products and operational standards of the product in each financial institution requires a standard and harmonization that is of course in accordance with the principles of Sharia and also refers to the fatwa issued by Majelis Ulama Indonesia (MUI). 
Sandy Aji Usman, Rasiam

OJK provides the guidelines of contractas a referral of financial institutions but is not binding. If looking at attachment 2 standard examples of murabahah financing Legal ground has been adjusted by Fatwa DSN-MUI No. 04/DSN-MUI/IV/2000 About Murabahah, Regulations of Bank Indonesia, and official letters from Bank Indonesia (SEBI), Broadly, the structure of contractis almost the same as the structure of UUJN, consisting of the deed head, deed body, and deed cover. The distinguishing is on before the head of the deed before the deed title is the opening paragraph using the Arabic or Latin "Bismillahhirrahmannirrahim", And after deed number there is quotation of verse in Al-Qur'an Surah Al-Maidah 5: 1, Al-Baqarah 2: 275, Surah An-Nisaa' 4: 29, Surah Al-Israa 17: 34 The quotations are adapted to the sharia products used, but some are compiled after the verses of the Qur'an begin to act as deed, deed body, and deed cover. For the deed that forms under the form of the structure shall remain valid, but if the structure as a guideline issued by the 0JK form is made in an authentic or made by a notary official can impact the quality of the deed Such authentic.

The example is the customs of the sharia deed which is used largely as a notary as a form of application of sharia principles applied to financial institutions or Sharia transactions, if viewed by example Murabahah product standard book issued by 0JK there is a difference in the arrangement or structure of the deed/contract, this is understandable because the structure of the deed for the contract issued through the Murabahah product standard book is a form of under hand deed.

Quotation of Al-Qur'an verse, Surah Al-Maidah 5: 1, Al-Baqarah 2: 275, Surah An-Nisaa' 4: 29, Surah Al-Israa 17: 34 Sharia transaction agreement is not mistaken, it can be seen from surah Az-Zaariyaat 51: 55which means "And remind, for indeed, the reminder benefits the believers.", This verse suggests that every human being will give warning or advice to other human beings with the Qur'an, because the warning is beneficial to people of faith, both reminiscent in writing or verbal that The human-made contractis bound horizontally and vertically, thus sharia Muslims can be allowed to cite the verses and then be inserted in notary deed. 
Quotation/Parenthesis Qur'an Verse Before ...

\section{Conclusion}

In Islamic Sharia or fatwa is not regulated about the structure of the deed on the deed authentic or under the hands, but which is governed only the principles or basic rules only. Contracton Sharia financial institution form ALKitabah guidelines used using product standard book that is issued by OJK is a form under the hands, but in the development of the structure of the contract used refers to the customs made by a notary official or an authentic deed.

Authentic deed structure made by notary public, especially the deed in financial institution that includes the quotation of Qur'anverses using the Indonesian language before the title of deed does not include provisions UUJN, the addition of the form before the title of deed Does not diminish from the essence of the structure of the deed as stipulated in article 38 UUJN but add more value to the quality of the deed, the deed is such an authentic deed has the strength of perfect proof. Insert the quotation is intended as a reminder or remind people of faith with verses of surah (AzZaariyaat 51:55) so that it does not contradict the Islamic Sharia.

The absence of the form of the standard structure of sharia agreement both for sharia transactions and in particular sharia financial institutions should be the financial Services Authority in collaboration with the organization of Indonesian Notary Association (INI) who is already experts to Create authentic deed in the form of raw in accordance with the UUNJ, to construct a good deed structure, remember the Sharia financial institution in conducting its contract in the form of Al-Kitabah.

In order for a notary to make an authentic deed for the agreement in the sharia financial institutions to pay attention to the language used, because for the sharia transactions many use the term or the Arabic language, so it is necessary to define or the meaning of The Arabic language in order not to violate the provisions of UUJN resulting in a reduction in the quality of deed. 
Sandy Aji Usman, Rasiam

\section{References}

Ascaraya, Akad dan Produk Bank Syariah, Rajawali Pers, Jakarta, 2017

Asutay, The Evolution of Islamic Finance and Key Development, Cambrige University, Central Banking Training, 2011

AL-ARBAH | 80 Darsono, Ali Sakti Dkk, Dinamika Produk dan Akad Keuangan Syariah Di Indonesia, Rajawali Pres, Depok, 2017

Henry R. Cheesman, Contemporary Business Law, Cet. Ke 3, New Jersy: Prentice Hall, 2000, 187

Mariam Darus Badrulzaman, Aneka Hukum Bisnis, Alumni, Cetakan ke-2, 2005

Munir Fuadi, Hukum kontrak dari Sudut Pandang Bisnis, Citra Aditya Bakti, Bandung, 1994

R. Setiawan, Pokok-Pokok Hukum Perikatan, Putra Abardin, Bandung, 2007

Salim dan Muhaimin, Teknik Pembuatan Akta Akad Pembiayaan Syariah, Rajawali Pers, Depok, 2018

Standar Produk Perbankan Syariah - Murabahah, 2016

Syaichulhadi Pernomo, Hukum Bisnis: Membangun Wacana Itegritas Perundangan Nasional dengan syariah, UIN-Malang Pers, 2009

Syamsul Anwar, Hukum Perjanjian Syariah Studi Tentang Teori Akad Dalam Fikih Muamalat, Rajawali Pers, Jakarta, 2007

Yulia, Perbankan Syariah, Stain Pontianak Pers, Pontianak, 2012 